\title{
Differential Control of Opioid Antinociception to Thermal Stimuli in a Knock-In Mouse Expressing Regulator of G-Protein Signaling-Insensitive $\mathrm{G} \alpha_{\mathrm{o}}$ Protein
}

\author{
Jennifer T. Lamberts, ${ }^{1}$ Chelsea E. Smith, ${ }^{1}$ Ming-Hua Li, ${ }^{3}$ Susan L. Ingram, ${ }^{3}$ Richard R. Neubig, ${ }^{1,2}$ and John R. Traynor ${ }^{1}$ \\ ${ }^{1}$ Department of Pharmacology, and ${ }^{2}$ Center for the Discovery of New Medicines, University of Michigan Medical School, Ann Arbor, Michigan 48109, and \\ ${ }^{3}$ Department of Neurological Surgery, Oregon Health and Science University, Portland, Oregon 97239
}

\begin{abstract}
Regulator of G-protein signaling (RGS) proteins classically function as negative modulators of G-protein-coupled receptor signaling. In vitro, RGS proteins have been shown to inhibit signaling by agonists at the $\mu$-opioid receptor, including morphine. The goal of the present study was to evaluate the contribution of endogenous RGS proteins to the antinociceptive effects of morphine and other opioid agonists. To do this, a knock-in mouse that expresses an RGS-insensitive (RGSi) mutant $\mathrm{G} \alpha_{\mathrm{o}}$ protein, $\mathrm{G} \alpha_{\mathrm{o}}{ }^{\mathrm{G} 184 \mathrm{~S}}$ ( $\mathrm{G} \alpha_{\mathrm{o}} \mathrm{RGSi}$ ), was evaluated for morphine or methadone antinociception in response to noxious thermal stimuli. Mice expressing G $\alpha_{\mathrm{o}}$ RGSi subunits exhibited a naltrexone-sensitive enhancement of baseline latency in both the hot-plate and warm-water tail-withdrawal tests. In the hot-plate test, a measure of supraspinal nociception, morphine antinociception was increased, and this was associated with an increased ability of opioids to inhibit presynaptic GABA neurotransmission in the periaqueductal gray. In contrast, antinociception produced by either morphine or methadone was reduced in the tail-withdrawal test, a measure of spinal nociception. In whole-brain and spinal cord homogenates from mice expressing $\mathrm{G} \alpha_{0}$ RGSi subunits, there was a small loss of $\mathrm{G} \alpha_{0}$ expression and an accompanying decrease in basal G-protein activity. Our results strongly support a role for RGS proteins as negative regulators of opioid supraspinal antinociception and also reveal a potential novel function of RGS proteins as positive regulators of opioid spinal antinociceptive pathways.
\end{abstract}

\section{Introduction}

Morphine produces analgesia by activating the $\mu$-opioid receptor (MOR), a member of the G-protein-coupled receptor (GPCR) superfamily. MOR stimulation results in the activation of heterotrimeric $\mathrm{G}_{\mathrm{i} / \mathrm{o}}$ proteins composed of a $\mathrm{G} \alpha_{\mathrm{i} / \mathrm{o}}$ subunit and a $G \beta \gamma$ heterodimer. Signaling is terminated via the intrinsic GTPase activity of the $\mathrm{G} \alpha_{\mathrm{i} / \mathrm{o}}$ subunit, and this process is enhanced by regulator of G-protein signaling (RGS) proteins. RGS proteins are GTPase-accelerating proteins (GAPs) and therefore reduce $\mathrm{G} \alpha_{\mathrm{i} / \mathrm{o}}$-mediated signaling duration and intensity (De Vries et al., 2000; Ross and Wilkie, 2000; Hollinger and Hepler, 2002). Therefore, RGS proteins have been proposed as drug targets for several disease states, including both pain and addiction (Neubig and Siderovski, 2002; Traynor and Neubig, 2005).

\footnotetext{
Received Nov. 8, 2012; revised Jan. 14, 2013; accepted Jan. 20, 2013.

Author contributions: J.T.L. and J.R.T. designed research; J.T.L., C.E.S., M.-H.L., and S.L.I. performed research; R.R.N. contributed unpublished reagents/analytic tools; J.T.L., C.E.S., M.-H.L., S.L.I., and J.R.T. analyzed data; J.T.L. and J.R.T. wrote the paper.

This research was supported by NIH Grants DA27625 (to S.LI.I); GM039561 (to R.R.N.); and DA04087 and MH083754 (to J.R.T.). J.T.L. was supported by a predoctoral fellowship from the Pharmaceutical Research and Manufacturers of America Foundation and NIH Training Grants DA007267 and GM007767. We thank Claire Meurice, Joe Guel, and Jasmine Schimmel for assistance in animal husbandry, Lisa Rosenthal for technical contributions, and Dr. Emily Jutkiewicz for helpful discussions.

The authors declare no competing financial interests.

Correspondence should be addressed to Dr. John R. Traynor, 1150 West Medical Center Drive, 1301 MSRB III, Ann Arbor, MI 48109-5632. E-mail: jtraynor@umich.edu.

DOI:10.1523/JNEUROSCI.5470-12.2013

Copyright $\odot 2013$ the authors $\quad 0270-6474 / 13 / 334369-09 \$ 15.00 / 0$
}

There are 20 RGS proteins with GAP activity. These are divided into several families based on the structure of the RGS homology domain that binds $\mathrm{G} \alpha$ and is responsible for the classical GAP function. RGS proteins have been demonstrated to regulate signaling negatively through several GPCRs in vitro, including MOR (Potenza et al., 1999; Clark et al., 2003; Clark and Traynor, 2004; Psifogeorgou et al., 2007). Studies evaluating the contribution of individual RGS proteins to opioid effects in vivo have generally used gene knock-down or knock-out strategies in mice (for examples, see Zachariou et al., 2003; Garzón et al., 2003, 2004, 2005; Grillet et al., 2005; Han et al., 2010). However, the phenotypic effect(s) of eliminating a single RGS protein is often reported to be quite small (Grillet et al., 2005), which could be due to developmental compensations and/or redundancy within the RGS family.

The aim of the present study was to test the hypothesis that endogenous RGS proteins regulate opioid antinociception negatively via interaction with $\mathrm{G} \alpha_{\mathrm{o}}$ subunits using a novel knock-in mouse that expresses the RGS-insensitive (RGSi) mutant $\mathrm{G} \alpha_{\mathrm{o}}$ protein, $\mathrm{G} \alpha_{\mathrm{o}}{ }^{\mathrm{G} 184 \mathrm{~S}}$ ( $\mathrm{G} \alpha_{\mathrm{o}}$ RGSi) (Goldenstein et al., 2009). The relationship between RGS proteins and $\mathrm{G} \alpha_{\mathrm{o}}$ is of particular interest in light of our previous work demonstrating that $\mathrm{G} \alpha$ o plays a significant role in opioid antinociception (Lamberts et al., 2011). For these studies, $\mathrm{G} \alpha_{\mathrm{o}}$ RGSi heterozygous knock-in mice ( $\left.\mathrm{G} \alpha_{\mathrm{o}}+/ \mathrm{GS}\right)$ were compared with wild-type littermates because homozygous knock-in mice ( $\mathrm{G} \alpha_{\mathrm{o}} \mathrm{GS} / \mathrm{GS}$ ) are not viable (Goldenstein et al., 2009). Morphine or methadone antinociception was evaluated in $\mathrm{G} \alpha_{\mathrm{o}}+/ \mathrm{GS}$ mice using two different noxious 
thermal stimuli: the hot-plate test for supraspinal nociception and the warm-water tail-withdrawal test for spinal nociception. In addition, opioid modulation of GABA synaptic transmission was monitored in periaqueductal gray (PAG) neurons. Loss of RGS activity toward $\mathrm{G} \alpha$ o resulted in prolonged baseline latencies in both nociceptive tests due to an enhancement of endogenous opioid peptide signaling. Moreover, there was an enhanced potency of morphine to elicit antinociception in the hot-plate test and to inhibit GABA release in the PAG in $G \alpha_{o}+/ G S$ mice, all pointing to negative regulation of MOR signaling by RGS proteins. In contrast, a paradoxical decrease in antinociception was observed in the tail-withdrawal test.

\section{Materials and Methods}

Transgenic mice. $\mathrm{G} \alpha_{\mathrm{o}}$ RGSi mice were generated as described previously (Fu et al., 2004; Fu et al., 2006; Huang et al., 2006; Goldenstein et al., 2009) and were backcrossed for 6 generations onto a 129S1/SvImJ background. $\mathrm{G} \alpha_{\mathrm{o}}+/ \mathrm{GS}$ and wild-type littermates were obtained at the expected Mendelian frequency for wild type and $\mathrm{G} \alpha_{\mathrm{o}}+/ \mathrm{GS}$ crosses (data not shown). Experiments were performed using male and female mice between 10 and 25 weeks of age and weighing between 20 and $25 \mathrm{~g}$. Mice were group-housed by sex with unlimited access to food and water. Lights were maintained on a $12 \mathrm{~h}$ light/dark cycle (lights on at 7:00), and all testing was performed during the light phase. Studies were performed in accordance with the Guide for the Care and Use of Laboratory Animals established by the National Institutes of Health and all experimental protocols were approved by the University of Michigan Committee on the Use and Care of Animals.

Antinociceptive tests. Supraspinal antinociception was evaluated in the hot-plate test and spinal antinociception was measured in the warmwater tail-withdrawal test using a cumulative dosing procedure, as described previously (Lamberts et al., 2011). Briefly, mice were administered saline followed by $3-4$ increasing doses of morphine or methadone in $30 \mathrm{~min}$ intervals, and latency was evaluated $30 \mathrm{~min}$ after each intraperitoneal injection. To evaluate the role of endogenous opioid peptides in baseline nociception, latency was determined $30 \mathrm{~min}$ after injection of the opioid antagonist naltrexone (NTX; $10 \mathrm{mg} / \mathrm{kg}$, i.p.).

For the hot-plate test, mice were placed on a hot-plate analgesia meter (Columbus Instruments) maintained at $52.0 \pm 0.2^{\circ} \mathrm{C}$ and the latency to lick the forepaw(s) or jump was measured with a cutoff time of $60 \mathrm{~s}$ to prevent tissue damage. For the tail-withdrawal test, mice were lightly restrained and the distal tip of the mouse's tail was placed in a water bath (Fisher Scientific) maintained at $50.0 \pm 0.5^{\circ} \mathrm{C}$. The latency to tail flick was measured with a cutoff time of $20 \mathrm{~s}$.

Membrane preparation. Mice were killed by cervical dislocation and whole-brain tissue (minus cerebellum) or thoracic and lumbar spinal cord was removed and immediately chilled in ice-cold $50 \mathrm{~mm}$ Tris, pH 7.4 (Tris buffer). Homogenates were prepared as described previously (Lester and Traynor, 2006) and final membrane pellets were resuspended in Tris buffer and stored at $-80^{\circ} \mathrm{C}$ until use unless otherwise indicated. Protein content was determined by the method of Bradford (Bradford, 1976).

Western blot analysis of G-proteins. Whole-brain or spinal cord homogenates $(20 \mu \mathrm{g}$ of protein) were mixed with sample buffer $(63 \mathrm{~mm}$ Tris, pH 6.8, with $2 \%$ SDS, $10 \%$ glycerol, $0.008 \%$ bromophenol blue, and $50 \mathrm{~mm}$ dithiothreitol) and separated by SDS-PAGE on polyacrylamide gels. Proteins were transferred to nitrocellulose (Pierce) and probed with rabbit polyclonal anti-G $\alpha_{\mathrm{o}}$ (1:1000; Santa Cruz Biotechnology). Samples were also probed with mouse monoclonal anti- $\alpha$-tubulin (1:1000; Sigma-Aldrich) as a loading control. Blots were then incubated with horseradish peroxidase-conjugated goat anti-mouse or goat anti-rabbit secondary antibody $(1: 10,000)$ and immunoreactivity was detected by enhanced chemiluminesence in an EpiChem3 Benchtop Darkroom (UVP). Band densities were quantified using ImageJ software (http://rsbweb.nih.gov/ij/index.html).

Receptor-binding assays. To evaluate total opioid receptor and total MOR expression, homogenates from whole brains (100 $\mu \mathrm{g}$ of protein) or spinal cord (100-200 $\mu \mathrm{g}$ of protein, freshly prepared) were incubated in
Tris buffer with the radiolabeled opioid antagonist $\left[{ }^{3} \mathrm{H}\right]$ diprenorphine ( $\left.\left[{ }^{3} \mathrm{H}\right] \mathrm{DPN} ; 4 \mathrm{nM}\right)$ in the absence or presence of the MOR-selective antagonist D-Phe-Cys-Tyr-D-Trp-Arg-Thr-Pen-Thr-NH ${ }_{2}$ (CTAP; 300 nM) to define MOR. To measure high-affinity MOR expression, homogenates from whole brain (100 $\mu \mathrm{g}$ of protein) were incubated in Tris buffer with increasing concentrations of the radiolabeled MOR-selective agonist $\left[{ }^{3} \mathrm{H}\right]\left(\mathrm{D}-\mathrm{Ala}^{2}, \mathrm{~N}-\mathrm{MePhe}^{4}, \mathrm{Gly}-\mathrm{ol}^{5}\right)$ enkephalin ([ $\left.{ }^{3} \mathrm{H}\right] \mathrm{DAMGO} ; 0.24-44$ $\mathrm{nM})$. Homogenates from spinal cord $(100-200 \mu \mathrm{g}$ of protein freshly prepared) were incubated in Tris buffer with $12 \mathrm{~nm}\left[{ }^{3} \mathrm{H}\right]$ DAMGO. All binding reactions were incubated for $60 \mathrm{~min}$ at $25^{\circ} \mathrm{C}$. Nonspecific binding was evaluated in the presence of the opioid antagonist naloxone (NAL; $10 \mu \mathrm{M}$ ). Reactions were stopped by rapid filtration through GF/C filter mats (Whatman) using an MLR-24 harvester (Brandel). Bound radioactivity was determined by liquid scintillation counting using a Wallac 1450 MicroBeta counter (PerkinElmer).

$\left[{ }^{35} S\right]$ GTP $\gamma S$-binding assays. To measure G-protein activity, the incorporation of a slowly hydrolyzed GTP analog, guanosine-5'-O-(3$\left[{ }^{35} \mathrm{~S}\right]$ thio)triphosphate $\left(\left[{ }^{35} \mathrm{~S}\right] \mathrm{GTP} \gamma \mathrm{S}\right)$, into activated $\mathrm{G} \alpha$ subunits was monitored ex vivo. Homogenates from whole brain (10 $\mu \mathrm{g}$ of protein) or spinal cord (25-50 $\mu \mathrm{g}$ of protein, freshly prepared) were preincubated in $\left[{ }^{35}\right.$ S]GTP $\gamma$ S-binding buffer (50 mm Tris, $5 \mathrm{~mm} \mathrm{MgCl}_{2}, 100 \mathrm{~mm} \mathrm{NaCl}$, and $1 \mathrm{~mm}$ EDTA, pH 7.4, with $2 \mathrm{~mm}$ dithiothreitol, $100 \mu \mathrm{M}$ GDP, and 0.4 $\mathrm{U} / \mathrm{ml}$ adenosine deaminase) for $10 \mathrm{~min}$ at $25^{\circ} \mathrm{C}$ with or without opioid agonist (DAMGO, morphine, or methadone). Reactions were started by the addition of $0.1 \mathrm{nM}\left[{ }^{35} \mathrm{~S}\right] \mathrm{GTP} \gamma \mathrm{S}$, followed by incubation for $90 \mathrm{~min}$ at $25^{\circ} \mathrm{C}$. Nonspecific binding was evaluated in the presence of $10 \mu \mathrm{M}$ unlabeled GTP $\gamma$ S. Binding reactions were stopped by rapid filtration and bound radioactivity was measured by liquid scintillation counting, as described above.

Electrophysiology. Mice were deeply anesthetized with isoflurane and brains were rapidly removed and placed in ice-cold cutting buffer $(75 \mathrm{mM}$ $\mathrm{NaCl}, 2.5 \mathrm{~mm} \mathrm{KCl}, 0.1 \mathrm{~mm} \mathrm{CaCl}_{2}, 6 \mathrm{~mm} \mathrm{MgSO}_{4}, 1.2 \mathrm{~mm} \mathrm{NaH}_{2} \mathrm{PO}_{4}, 25 \mathrm{~mm}$ $\mathrm{NaHCO}_{3}, 2.5 \mathrm{~mm}$ D-glucose, and $50 \mathrm{~mm}$ sucrose). Coronal sections $(\sim 230 \mu \mathrm{m})$ containing the PAG were sliced in cutting buffer oxygenated with $95 \% \mathrm{O}_{2}$ and $5 \% \mathrm{CO}_{2}$. Slices were then maintained at $35^{\circ} \mathrm{C}$ in oxygenated artificial CSF $\left(126 \mathrm{~mm} \mathrm{NaCl}, 2.5 \mathrm{~mm} \mathrm{KCl}, 2.4 \mathrm{mM} \mathrm{CaCl}_{2}, 1.2 \mathrm{~mm}\right.$ $\mathrm{MgCl}_{2}, 1.2 \mathrm{~mm} \mathrm{NaH}_{2} \mathrm{PO}_{4}, 21.4 \mathrm{~mm} \mathrm{NaHCO}_{3}$, and $11.1 \mathrm{~mm}$ D-glucose, $\mathrm{pH}$ 7.4 , at 300-310 mOsm) until experimentation.

Whole-cell patch-clamp recordings were made from visually identified PAG neurons. Patch pipettes were pulled from borosilicate glass (WPI) on a two-stage puller (Narishige). Pipettes had a resistance of 2-4 M $\Omega$ and intracellular solutions contained $130 \mathrm{~mm} \mathrm{CsCl}, 5.4 \mathrm{~mm} \mathrm{KCl}, 0.1 \mathrm{mM} \mathrm{CaCl}_{2}, 2 \mathrm{~mm}$ $\mathrm{MgCl}_{2}, 10$ mм HEPES, 1.1 mм EGTA, 30 mm D-glucose, 4 mм Mg-ATP, and $1 \mathrm{~mm}$ Na-GTP, pH 7.3, at 280-290 mOsm. Whole-cell series resistance was compensated for by $\sim 80 \%$. Evoked GABA-mediated IPSCs (eIPSCs) were elicited with a bipolar stimulating electrode placed $\sim 200-300 \mathrm{~mm}$ distally from the recorded cell at a holding potential of $-70 \mathrm{mV}$ in the presence of the AMPA receptor antagonist 6-nitro-2,3-dioxo-1,4-dihydrobenzo[f] quinoxaline-7-sulfonamide ( $5 \mu \mathrm{M})$. Stimulation pulses $(2 \mathrm{~ms})$ were delivered at $0.05 \mathrm{~Hz}$. Currents were collected at $2 \mathrm{kHz}$ and digitized at $5 \mathrm{kHz}$ using an Axopatch 200B amplifier controlled by Axograph Data Acquisition software (Axograph X). During each experiment, a voltage step of $-10 \mathrm{mV}$ from the holding potential was applied periodically to monitor cell capacitance and access resistance. Recordings in which access resistance or capacitance changed by $>15 \%$ during the experiment were excluded from data analysis.

Drugs. For behavioral experiments, all drugs were diluted in sterile water. Morphine sulfate was from RTI, NTX hydrochloride was from Endo Pharmaceuticals, and l-methadone hydrochloride was from Eli Lilly. $\left[{ }^{3} \mathrm{H}\right] \mathrm{DPN}$, $\left[{ }^{3} \mathrm{H}\right] \mathrm{DAMGO}$, and $\left[{ }^{35} \mathrm{~S}\right] \mathrm{GTP} \gamma \mathrm{S}$ were from PerkinElmer. Adenosine deaminase was from Calbiochem. DAMGO, CTAP, NAL, $\left(\mathrm{Met}^{5}\right)$ enkephalin (ME), and all other chemicals were from Sigma-Aldrich unless otherwise stated.

Data analysis. All data were analyzed using Prism 5 software (GraphPad). Differences between genotypes were evaluated using Student's unpaired $t$ test or two-way ANOVA with Bonferroni's post-test, where appropriate. For all statistical tests, significance was set at $p<0.05$ and was adjusted for multiple comparisons if necessary. Initial statistical analysis revealed a lack of a sex $\times$ genotype interaction for any measure, so data from both male and female mice were pooled for final genotype comparisons. In vivo potency $\left(\mathrm{ED}_{50}\right)$ was calculated by fitting the compiled 


\section{Hot plate test}

a

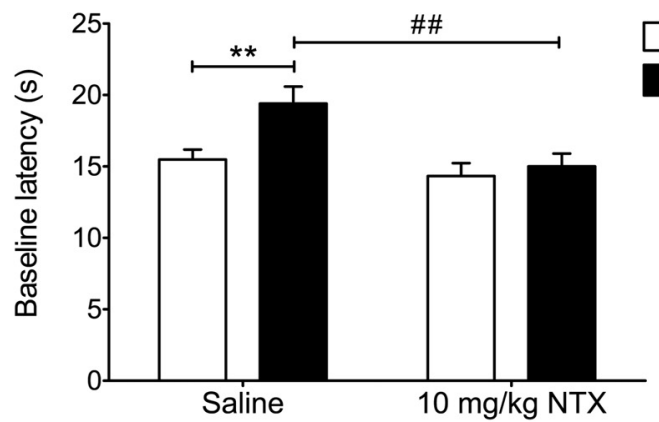

b

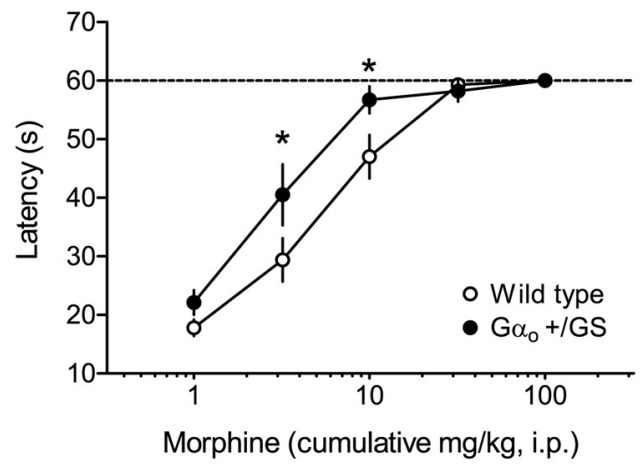

C

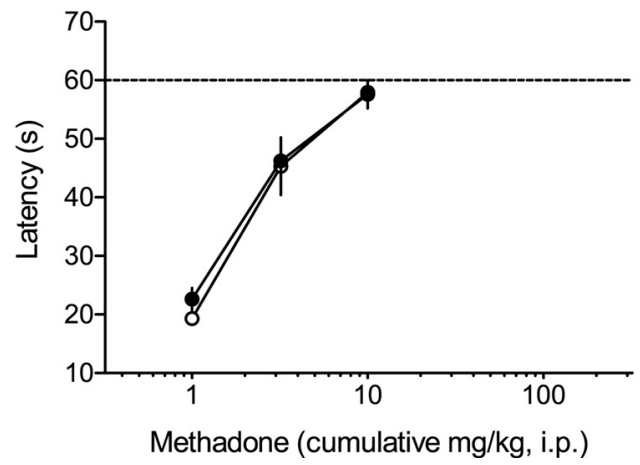

Figure 1. Baseline nociception and opioid antinociception in the $52^{\circ} \mathrm{C}$ hot-plate test in wildtype and $\mathrm{G} \alpha_{0}+/ \mathrm{GS}$ mice. $\boldsymbol{a}$, Baseline hot-plate latency was evaluated $30 \mathrm{~min}$ after saline (wild type, $n=24 ; G \alpha_{0}+/ G S, n=18$ ) or NTX (wild type, $n=15 ; G \alpha_{0}+/ G S, n=13$ ). ${ }^{* *} p<0.01$ compared with saline-treated wild-type mice, ${ }^{\# \#} p<0.01$ compared with saline-treated $G \alpha_{0}+/ G S$ mice by Bonferroni's post-test. $\boldsymbol{b}, \boldsymbol{c}$, Opioid supraspinal antinociception was evaluated as hot-plate latency 30 min after increasing cumulative doses of morphine (wild type, $n=$ $6-11 ; G \alpha_{0}+/ G S, n=6-9 ; \boldsymbol{b}$ ) or methadone (wild type, $n=12 ; G \alpha_{0}+/ G S, n=9 ; \boldsymbol{c}$ ). ${ }^{*} p<$ 0.05 compared with wild-type mice at the corresponding dose by Bonferroni's post-test. Legend in $\boldsymbol{b}$ also describes $\boldsymbol{c}$. Dotted lines indicate the test cutoff time. All data are plotted as the mean \pm SEM.

antinociception data to an agonist versus response curve (Hill slope $=1$ ); maximal binding $\left(B_{\max }\right)$ and binding affinity $\left(K_{\mathrm{d}}\right)$ were derived by fitting each radioligand binding experiment to a one-site saturation-binding curve (Hill slope $=1$ ); and in vitro potency $\left(\mathrm{EC}_{50}\right)$ was calculated by fitting individual $\left[{ }^{35} \mathrm{~S}\right] \mathrm{GTP} \gamma \mathrm{S}$-binding experiments to an agonist versus response curve $($ Hill slope $=1)$. All data are reported as the means $\pm \mathrm{SEM}$ except $\mathrm{ED}_{50}$ values, which are expressed as the means and 95\% CI.

\section{Results}

$\mathrm{G} \alpha_{\mathrm{o}}+/ \mathrm{GS}$ mice demonstrate enhanced morphine antinociception in the hot-plate test

We have shown previously that $\mathrm{G} \alpha_{\mathrm{o}}$ plays an important role in opioid antinociception (Lamberts et al., 2011). To determine

\section{Warm-water tail withdrawal test}

a

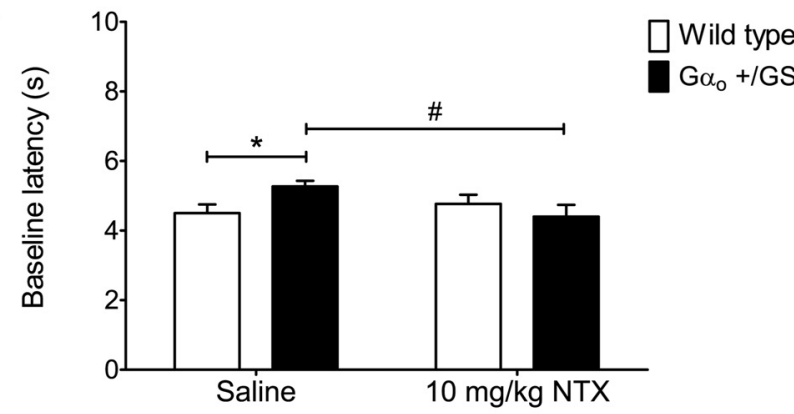

b

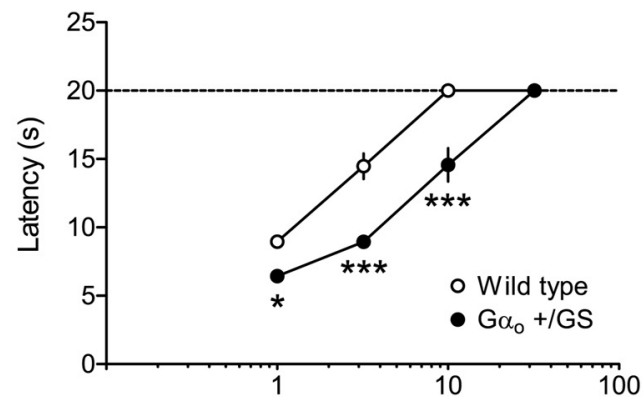

Morphine (cumulative $\mathrm{mg} / \mathrm{kg}$, i.p.)

C

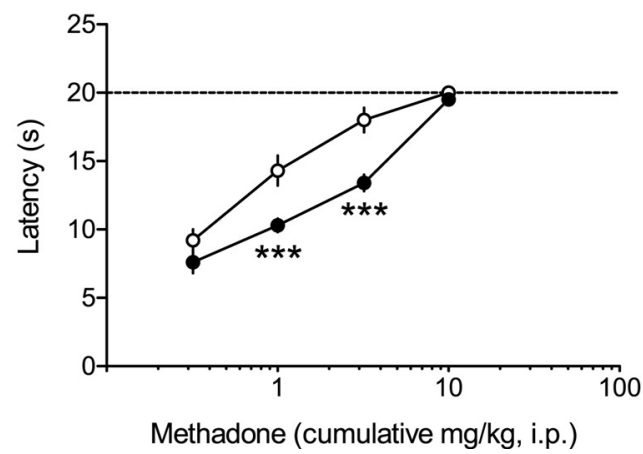

Figure 2. Baseline nociception and opioid antinociception in the $50^{\circ} \mathrm{C}$ warm-water tailwithdrawal test in wild-type and $G \alpha_{0}+/ G S$ mice. $\boldsymbol{a}$, Baseline tail-flick latency was evaluated 30 min after saline (wild type, $n=21 ; G \alpha_{0}+/ G S, n=24$ ) or NTX (wild type, $n=23$; $\left.G \alpha_{0}+/ G S, n=13\right) .{ }^{*} p<0.05$ compared with saline-treated wild-type mice, ${ }^{\#} p<0.05$ compared with saline-treated $G \alpha_{0}+/ G S$ mice by Bonferroni's post-test. $\boldsymbol{b}, \boldsymbol{c}$, Opioid spinal antinociception was evaluated as tail-flick latency $30 \mathrm{~min}$ after increasing doses of morphine (wild type, $n=11 ; G \alpha_{0}+/ G S, n=10 ; \boldsymbol{b}$ ) or methadone (wild type, $n=6-10 ; G \alpha_{0}+/ G S$, $n=8-14 ; c) .{ }^{*} p<0.05,{ }^{* * *} p<0.001$ compared with wild-type mice at the corresponding dose by Bonferroni's post-test. Legend in $\boldsymbol{b}$ also describes $\boldsymbol{c}$. Dotted lines indicate the test cutoff time. All data are plotted as the mean \pm SEM.

whether antinociception mediated by $\mathrm{G} \alpha_{\mathrm{o}}$ is modulated by interactions with RGS proteins, in the present study, $\mathrm{G} \alpha_{\mathrm{o}}+/ \mathrm{GS}$ mice were evaluated for opioid supraspinal antinociception using the $52^{\circ} \mathrm{C}$ hot-plate test (Fig. 1). In the absence of agonist, baseline hot-plate latency was significantly prolonged in $\mathrm{G} \alpha_{\mathrm{o}}+/ \mathrm{GS}$ mice compared with wild-type controls $(p<0.01$; Fig. $1 a)$. To evaluate whether the increase in baseline hot-plate latency was due to enhanced opioidergic tone, a separate group of mice was pretreated with the opioid antagonist NTX $(10 \mathrm{mg} / \mathrm{kg}$, i.p. $)$ before determination of hot-plate latency (Fig. 1a). Pretreatment with NTX blocked the increase in baseline hot-plate latency in $\mathrm{G} \alpha_{\mathrm{o}}$ $+/$ GS mice $(p<0.01)$, but had no effect in wild-type controls $(p>0.05)$. Two-way ANOVA revealed significant effects of both 
genotype $\left(F_{(1,66)}=5.8, p=0.019\right)$ and treatment $\left(F_{(1,66)}=8.4, p=0.005\right)$, with a nonsignificant genotype $\times$ treatment interaction $\left(F_{(1,66)}=2.9, p=0.094\right)$.

Morphine evoked a dose-dependent increase in hot-plate latency that was significantly enhanced ( $\sim 2$-fold) in $\mathrm{G} \alpha_{\mathrm{o}}+/ \mathrm{GS}$ mice compared with wild-type controls (Fig. $1 b)$. In wild-type mice, the potency $\left(\mathrm{ED}_{50}\right)$ of morphine was 2.71 (95\% CI, 2.10$3.49) \mathrm{mg} / \mathrm{kg}$ compared with 1.46 (95\% CI, 1.11-1.93) $\mathrm{mg} / \mathrm{kg}$ in $\mathrm{G} \alpha_{\mathrm{o}}+/ \mathrm{GS}$ mice. There were significant effects of both dose $\left(F_{(4,71)}=79, p<0.001\right)$ and genotype $\left(F_{(1,71)}=7.7, p=0.007\right)$, whereas the dose $X$ genotype interaction was not significant $\left(F_{(4,71)}=2.0, p=0.100\right)$.

To determine whether this effect was specific to morphine, we also measured antinociception produced by the higherefficacy MOR agonist methadone. In contrast to morphine, there was no change in the antinociception produced by methadone in $\mathrm{G} \alpha_{\mathrm{o}}+/ \mathrm{GS}$ mice compared with wild-type littermates (Fig. 1c). The $\mathrm{ED}_{50}$ values for methadone were 1.41 (95\% CI, $1.01-1.96) \mathrm{mg} / \mathrm{kg}$ and 1.24 (95\% CI, 0.911.69) $\mathrm{mg} / \mathrm{kg}$ for wild-type and $\mathrm{G} \alpha_{\mathrm{o}}+/ \mathrm{GS}$ mice, respectively. Statistical analysis revealed a significant effect of dose $\left(F_{(2,57)}=\right.$ $74, p<0.001)$, but neither a significant effect of genotype $\left(F_{(1,57)}=0.27, p=\right.$ $0.608)$ nor a significant dose $\times$ genotype interaction $\left(F_{(2,57)}=\right.$ $0.18, p=0.839)$.

\section{Opioid antinociception is reduced in $\mathrm{G} \alpha_{\mathrm{o}}+/ \mathrm{GS}$ mice in the tail-withdrawal test}

To evaluate whether the enhancement of morphine antinociception in $\mathrm{G} \alpha_{\mathrm{o}}+/ \mathrm{GS}$ mice was specific to supraspinal pathways, antinociception was also evaluated using the $50^{\circ} \mathrm{C}$ warm-water tail-withdrawal test (Fig. 2). The tail-withdrawal test is thought to measure primarily spinal nociception and involves modulation of a simple spinal reflex (Irwin et al., 1951). At baseline, tail-flick latency was slightly prolonged in $\mathrm{G} \alpha_{\mathrm{o}}+/ \mathrm{GS}$ mice compared with wild-type littermates ( $p<0.05$; Fig. $2 a$ ). Similar to observations in the hot-plate test, pretreatment with NTX $(10 \mathrm{mg} / \mathrm{kg}$, i.p.) reversed the increase in tail-flick latency in $\mathrm{G} \alpha_{\mathrm{o}}+/ \mathrm{GS}$ mice $(p<$ $0.05)$, but did not affect tail-flick latency in wild-type animals $(p>0.05$; Fig. 2a). There was a significant genotype $\times$ treatment interaction $\left(F_{(1,77)}=5.2, p=0.026\right)$, although the main effects of neither genotype $\left(F_{(1,77)}=0.63, p=0.428\right)$ nor treatment $\left(F_{(1,77)}=\right.$ $1.4, p=0.236)$ were significant.

Increasing doses of morphine produced an increase in tail-flick latency that was significantly reduced ( $\sim 3$-fold) in $\mathrm{G} \alpha_{\mathrm{o}}+/ \mathrm{GS}$ mice compared with wild-type littermates (Fig. $2 b$ ), with $\mathrm{ED}_{50}$ values of 3.08 (95\% CI, 2.49-3.82) $\mathrm{mg} / \mathrm{kg}$ and 1.11 (95\% CI, 0.92-1.33) $\mathrm{mg} / \mathrm{kg}$, respectively. There were significant effects of both dose $\left(F_{(3,76)}=180, p<0.001\right)$ and genotype $\left(F_{(1,76)}=66, p<0.001\right)$, as well as a significant dose $\times$ genotype interaction $\left(F_{(3,76)}=10\right.$, $p<0.001)$.

Like morphine, methadone was also less potent $(\sim 2$-fold $)$ in $\mathrm{G} \alpha_{\mathrm{o}}+/ \mathrm{GS}$ mice compared with wild-type controls (Fig. $2 c$ ), with $\mathrm{ED}_{50}$ values of 0.27 (95\% CI, 0.22-0.34) $\mathrm{mg} / \mathrm{kg}$ and 0.12 (95\% CI,
$0.09-0.15) \mathrm{mg} / \mathrm{kg}$, respectively. There were significant effects of both dose $\left(F_{(3,78)}=77, p<0.001\right)$ and genotype $\left(F_{(1,78)}=23, p<\right.$ $0.001)$ and a significant dose $\times$ genotype interaction $\left(F_{(3,78)}=\right.$ $3.1, p=0.031)$.

\section{Opioid inhibition of GABA release is potentiated in PAG neurons from $\mathrm{G} \boldsymbol{\alpha}_{\mathrm{o}}+/ \mathrm{GS}$ mice}

One of the mechanisms by which opioids produce antinociception is by removing tonic GABA inhibition (i.e., by GABA disinhibition) of descending antinociceptive neurons that emanate from the PAG (Moreau and Fields, 1986; Reichling et al., 1988). This effect can be measured by evaluating the ability of opioids to inhibit eIPSCs in slices containing the PAG (Vaughan and Christie, 1997; Vaughan et al., 1997). To determine the role of RGS proteins in opioid-mediated GABA disinhibition, slices containing the PAG were isolated from wild-type and $\mathrm{G} \alpha_{\mathrm{o}}+/ \mathrm{GS}$ mice and the ability of either morphine or the higher-efficacy opioid peptide ME to inhibit eIPSCs was measured using whole-cell voltage-clamp electrophysiology (Fig. 3).

Superfusion of morphine inhibited the amplitude of GABA eIPSCs in both wild-type and $\mathrm{G} \alpha_{\mathrm{o}}+/ \mathrm{GS}$ mice, but the inhibition elicited by a submaximal concentration of morphine $(5 \mu \mathrm{M})$ was enhanced in slices from $\mathrm{G} \alpha_{\mathrm{o}}+/ \mathrm{GS}$ mice $(p<0.05$; Fig. $3 a)$. There were significant main effects of both concentration $\left(F_{(1,18)}=16, p<\right.$ $0.001)$ and genotype $\left(F_{(1,18)}=11, p=0.003\right)$, although the concentration $\times$ genotype interaction was not significant $\left(F_{(1,18)}=\right.$ $0.82, p=0.377)$. Similarly, application of ME at a concentration of either $300 \mathrm{nM}$ or $10 \mu \mathrm{M}$ resulted in a greater inhibition of eIPSCs in slices from $\mathrm{G} \alpha_{\mathrm{o}}+/ \mathrm{GS}$ mice $(p<0.05)$ compared with slices from wild-type littermates (Fig. $3 b$ ). There were significant effects of both concentration $\left(F_{(1,8)}=36, p<0.001\right)$ and geno- 


\section{Whole brain Spinal cord}

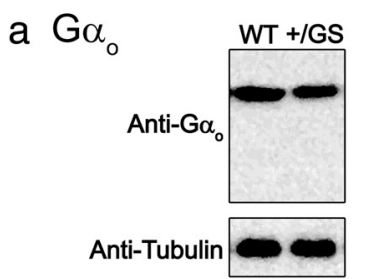

b $\mathrm{G \alpha}_{z}$

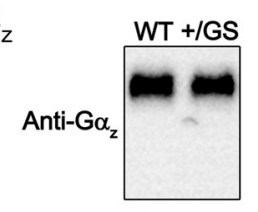

Anti-Tubulin

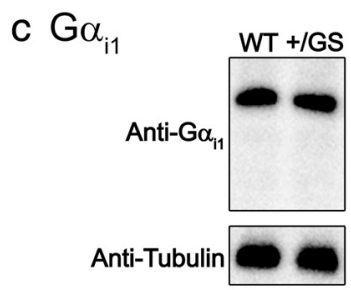

d $G \alpha_{i 2}$

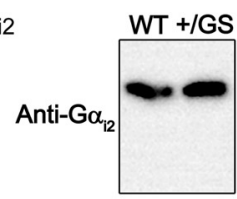

Anti-Tubulin

e $G \alpha_{i 3}$

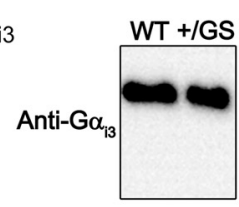

Anti-Tubulin

f $G \beta_{1-4}$
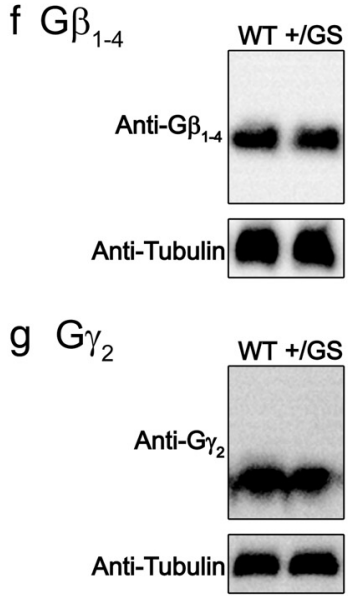
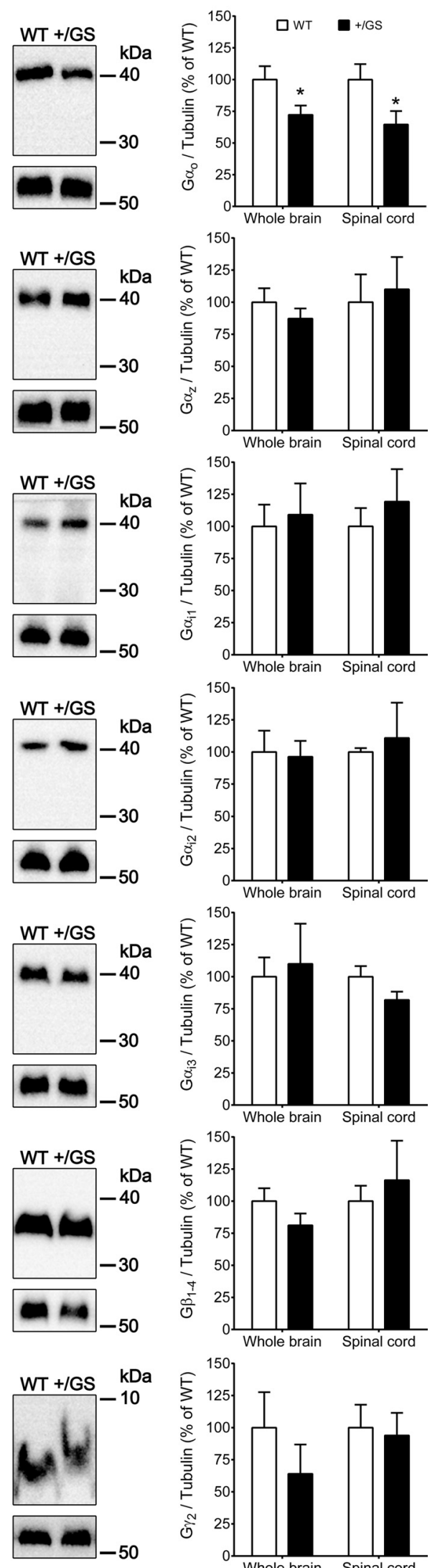

type $\left(F_{(1,8)}=21, p=0.002\right)$, whereas the concentration $\times$ genotype interaction was not significant $\left(F_{(1,8)}=0.00, p=\right.$ 0.989).

$\mathrm{G} \boldsymbol{\alpha}_{\mathrm{o}}+/ \mathrm{GS}$ mice exhibit a loss of $\mathrm{G} \boldsymbol{\alpha}_{\mathrm{o}}$ expression in brain and spinal cord To determine whether the knock-in mutation affected G-protein levels, wholebrain or spinal cord homogenates from $\mathrm{G} \alpha_{\mathrm{o}}+/ \mathrm{GS}$ mice were subjected to Western blot analysis of G-protein expression (Fig. 4). Quantification of Western blot images revealed that in $\mathrm{G} \alpha_{\mathrm{o}}+/ \mathrm{GS}$ mice, total $\mathrm{G} \alpha_{\mathrm{o}}$ protein expression was significantly reduced $(\sim 25-35 \%)$ in both whole brain $\left(t_{(14)}=2.2, p=0.048\right.$; Fig. $\left.4 a\right)$ and spinal cord $\left(t_{(12)}=2.2, p=0.049\right.$; Fig. $\left.4 a\right)$ compared with wild-type controls. In contrast, the expression of several other G-protein subunits, including $\mathrm{G} \alpha_{\mathrm{z}}, \mathrm{G} \alpha_{\mathrm{i} 1}$, $\mathrm{G} \alpha_{\mathrm{i} 2}, \mathrm{G} \alpha_{\mathrm{i} 3}, \mathrm{G} \beta_{1-4}$, and $\mathrm{G} \gamma_{2}$, was unchanged in either whole brain or spinal cord from $\mathrm{G} \alpha_{\mathrm{o}}+/ \mathrm{GS}$ mice ( $p>0.05$; Fig. $4 b-g)$.

We demonstrated previously that reduction of $\mathrm{G} \alpha$ o protein by $>50 \%$ in mice results in reduced high-affinity MOR expression with no change in total MOR number (Lamberts et al., 2011). To evaluate whether the smaller, $\sim 25-35 \%$ loss of $\mathrm{G} \alpha_{\mathrm{o}}$ expression in $\mathrm{G} \alpha_{\mathrm{o}}+/ \mathrm{GS}$ mice affected MOR levels, whole-brain or spinal cord homogenates were subjected to radioligand-binding analysis using the MOR-selective agonist $\left[{ }^{3} \mathrm{H}\right]$ DAMGO (Table 1). In homogenates from whole brain, saturation-binding experiments revealed no difference in $\left[{ }^{3} \mathrm{H}\right]$ DAMGO $B_{\max }$ between genotypes $\left(t_{(11)}=0.73, p=0.479\right.$; Table 1$)$. Furthermore, there were no differences in $\left[{ }^{3} \mathrm{H}\right] \mathrm{DAMGO} K_{\mathrm{d}}$ between $\mathrm{G} \alpha_{\mathrm{o}}+/ \mathrm{GS}$ mice and wild-type controls $\left(t_{(11)}=0.54, p=\right.$ 0.600 ; Table 1). Similarly, there were no changes in MOR expression in spinal cord homogenates from $\mathrm{G} \alpha_{\mathrm{o}}+/ \mathrm{GS}$ mice, as measured by $\left[{ }^{3} \mathrm{H}\right] \mathrm{DAMGO}$ binding at a maximal concentration $\left(12 \mathrm{nM} ; t_{(6)}=0.43\right.$, $p=0.683$; Table 1$)$. Total opioid receptor expression (MOR and $\delta$ - and $\kappa$-opioid receptors), as measured by the nonselective antagonist $\left[{ }^{3} \mathrm{H}\right] \mathrm{DPN}(4 \mathrm{nM})$, was not different in either whole brain $\left(t_{(9)}=0.57, p=\right.$

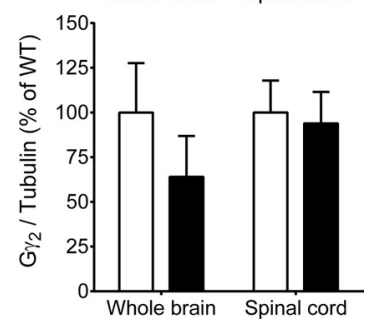

Figure 4. G-protein expression in whole-brain or spinal cord homogenates from wild-type (WT) and $\mathrm{G} \alpha_{0}+/ \mathrm{GS}(+/ \mathrm{GS})$ mice. $\boldsymbol{a}-\boldsymbol{g}$, Homogenates were separated by SDS-PAGE, transferred to nitrocellulose, and probed for the expression of $G \alpha_{0}(n=7-8$;

a), $G \alpha_{\mathrm{z}}(n=4-5 ; \boldsymbol{b}), \mathrm{G} \alpha_{\mathrm{i1}}(n=4-5 ; \boldsymbol{c}), \mathrm{G} \alpha_{\mathrm{i2}}(n=4-5 ; \boldsymbol{d})$, $\mathrm{G} \alpha_{\mathrm{i} 3}(n=4-5 ; \boldsymbol{e}), \mathrm{G} \beta_{1-4}(n=4-5 ; f)$, or $\mathrm{G} \gamma_{2}(n=4-5 ; \boldsymbol{g})$ using tubulin as a loading control. $G$-protein band densities were quantified in ImageJ and normalized to tubulin band densities, and data are plotted as a percentage of WT within each tissue. ${ }^{*} p<0.05$ compared with wild type in the same tissue by Student's $t$ test. Legend in $\boldsymbol{a}$ also describes $\boldsymbol{b}-\boldsymbol{g}$. All data are plotted as the mean \pm SEM. 
Table 1. Agonist and antagonist radioligand binding in whole brain or spinal cord homogenates from wild-type and $G \alpha_{0}+/ G S$ mice

\begin{tabular}{|c|c|c|c|c|c|}
\hline \multirow[b]{2}{*}{ Tissue } & \multirow[b]{2}{*}{ Genotype } & \multicolumn{2}{|c|}{$\left[{ }^{3} \mathrm{H}\right]$ DAMGO binding } & \multicolumn{2}{|c|}{$\left[{ }^{3} \mathrm{H}\right] \mathrm{DPN}$ binding } \\
\hline & & $\begin{array}{l}B_{\max } \\
\text { (fmol/mg } \\
\text { protein) }\end{array}$ & $K_{d}(n M)$ & $\begin{array}{l}\text { Total } \\
\text { (fmol/mg } \\
\text { protein) }\end{array}$ & $\begin{array}{l}\text { MOR } \\
\text { (fmol/mg } \\
\text { protein) }\end{array}$ \\
\hline \multirow[t]{2}{*}{ Whole brain } & Wild type & $219 \pm 23$ & $3.3 \pm 0.3$ & $357 \pm 56$ & $190 \pm 33$ \\
\hline & $\mathrm{G} \alpha_{0}+/ \mathrm{GS}$ & $198 \pm 18$ & $3.0 \pm 0.5$ & $312 \pm 56$ & $166 \pm 29$ \\
\hline \multirow[t]{2}{*}{ Spinal cord } & Wild type & $123 \pm 26$ & ND & $184 \pm 21$ & $98 \pm 16$ \\
\hline & $\mathrm{G} \alpha_{0}+/ \mathrm{GS}$ & $109 \pm 22$ & ND & $202 \pm 24$ & $116 \pm 19$ \\
\hline
\end{tabular}

MOR expression was measured by evaluating the amount of bound [ $\left.{ }^{3} \mathrm{H}\right] \mathrm{DPN}$ displaced by the MOR-selective antagonist CTAP $(300 \mathrm{nM})$. Data represent the mean \pm SEM (whole brain: $n=5-7$; spinal cord: $n=4)$. Each sample was assayed in duplicate. ND, Not determined.

$0.582)$ or spinal cord $\left(t_{(6)}=0.56, p=0.596\right)$ of $\mathrm{G} \alpha_{\mathrm{o}}+/ \mathrm{GS}$ mice compared with wild-type littermates (Table 1). MOR expression was isolated from the total pool of opioid receptors using the MORselective antagonist CTAP (300 nM). Neither whole brain $\left(t_{(9)}=\right.$ $0.56, p=0.590)$ nor spinal cord expression of $\operatorname{MOR}\left(t_{(6)}=0.73, p=\right.$ $0.495)$ was altered in $\mathrm{G} \alpha_{\mathrm{o}}+/ \mathrm{GS}$ mice compared with wild-type controls (Table 1).

To determine whether the loss of $\mathrm{G} \alpha_{\mathrm{o}}$ protein in $\mathrm{G} \alpha_{\mathrm{o}}+/ \mathrm{GS}$ mice was associated with a reduction in G-protein activation, opioid agonist-stimulated G-protein activity was evaluated in whole-brain or spinal cord homogenates using the $\left[{ }^{35} \mathrm{~S}\right] \mathrm{GTP} \gamma \mathrm{S}$ binding assay (Fig. 5; Table 2). In whole brain, basal G-protein activity was significantly lower in $\mathrm{G} \alpha_{\mathrm{o}}+/ \mathrm{GS}$ mice compared with wild-type littermates $\left(t_{(17)}=3.5, p=0.003\right.$; Table 2). However, $\left[{ }^{35} \mathrm{~S}\right] \mathrm{GTP} \gamma \mathrm{S}$ incorporation stimulated by the high-efficacy MOR-selective agonist DAMGO was unchanged in whole brain from $\mathrm{G} \alpha_{\mathrm{o}}+/ \mathrm{GS}$ mice (Fig. $5 a$, top). Statistical analysis of DAMGO concentration-response curves obtained in wholebrain homogenates from wild-type and $\mathrm{G} \alpha_{\mathrm{o}}+/ \mathrm{GS}$ mice revealed a significant effect of concentration $\left(F_{(7,128)}=53, p<0.001\right)$, whereas there was neither a significant effect of genotype $\left(F_{(1,128)}=\right.$ $0.45, p=0.503)$ nor a significant concentration $\times$ genotype interaction $\left(F_{(7,128)}=0.22, p=0.980\right)$. There was also no change in DAMGO potency $\left(\mathrm{EC}_{50}\right)$ between $\mathrm{G} \alpha_{\mathrm{o}}+/ \mathrm{GS}$ mice and wild-type littermates $\left(t_{(16)}=1.6, p=0.126\right.$; Table 2). In contrast, morphine-stimulated G-protein activation was attenuated in whole-brain homogenates from $\mathrm{G} \alpha_{\mathrm{o}}+/ \mathrm{GS}$ mice compared with wild-type controls (Fig. 5a, bottom). Analysis of the morphine concentration response in whole-brain homogenates from wildtype and $\mathrm{G} \alpha_{\mathrm{o}}+/ \mathrm{GS}$ mice demonstrated significant effects of both concentration $\left(F_{(7,112)}=36, p<0.001\right)$ and genotype $\left(F_{(1,112)}=\right.$ $6.6, p=0.012)$, although the concentration $\times$ genotype interaction was not significant $\left(F_{(7,112)}=0.92, p=0.493\right)$. However, there was no difference in the $\mathrm{EC}_{50}$ for morphine between $\mathrm{G} \alpha_{\mathrm{o}}+/ \mathrm{GS}$ and wild-type mice $\left(t_{(14)}=1.2, p=0.247\right.$; Table 2). $\mathrm{G}$-protein activation was also measured in whole-brain homogenates using a saturating concentration of methadone $(10 \mu \mathrm{M})$. $\left[{ }^{35} \mathrm{~S}\right] \mathrm{GTP} \gamma \mathrm{S}$ incorporation stimulated by methadone was unchanged in whole brain from $\mathrm{G} \alpha_{\mathrm{o}}+/ \mathrm{GS}$ mice (percent stimulation: $64.2 \pm 11, n=4$ ) compared with wild-type controls (percent stimulation: $69.0 \pm 15, n=3 ; t_{(5)}=0.27, p=0.801$ ).

In the spinal cord, there was also a reduction in basal $\left[{ }^{35} \mathrm{~S}\right] \mathrm{GTP} \gamma \mathrm{S}$ incorporation in $\mathrm{G} \alpha_{\mathrm{o}}+/ \mathrm{GS}$ mice $\left(t_{(8)}=2.4, p=\right.$ 0.042 ; Table 2). DAMGO stimulation of G-protein activation was not different between wild-type and $\mathrm{G} \alpha_{\mathrm{o}}+/ \mathrm{GS}$ spinal cord (Fig. $5 b$, top). There was a significant main effect of concentration $\left(F_{(7,32)}=88, p<0.001\right)$, although the effect of genotype $\left(F_{(1,32)}=\right.$ $0.25, p=0.623)$ and the concentration $\times$ genotype interaction were not significant $\left(F_{(7,32)}=0.08, p=0.999\right)$. Moreover, there was no difference in DAMGO $\mathrm{EC}_{50}$ between genotypes in this tissue $\left(t_{(4)}=0.14, p=0.892\right.$; Table 2). Morphine-stimulated G-protein activity was also unchanged in spinal cord from $\mathrm{G} \alpha_{\mathrm{o}}+/ \mathrm{GS}$ mice compared with wild-type littermates (Fig. $5 b$, bottom). There was a significant effect of concentration $\left(F_{(7,32)}=\right.$ $21, p<0.001)$, but there was no significant effect of genotype $\left(F_{(1,32)}=0.37, p=0.545\right)$ and no significant concentration $\times$ genotype interaction $\left(F_{(7,32)}=0.72, p=0.658\right)$. Moreover, morphine $\mathrm{EC}_{50}$ was not altered in spinal cord homogenates from $\mathrm{G} \alpha_{\mathrm{o}}+/ \mathrm{GS}$ mice compared with wild-type littermates $\left(t_{(4)}=1.1, p=0.332\right.$; Table 2).

\section{Discussion}

In this study, we show that endogenously expressed RGS proteins regulate opioid antinociception by acting at $\mathrm{G} \alpha_{\mathrm{o}}$. Mice expressing $\mathrm{G} \alpha_{\mathrm{o}}$ RGSi subunits demonstrated an opioid-dependent increase in baseline latency in two different thermal nociceptive tests: the hot-plate test, a measure of supraspinal nociception (Heinricher and Morgan, 1999), and the warm-water tailwithdrawal test, which primarily involves spinal nociceptive pathways (Irwin et al., 1951; Cesselin et al., 1999). Furthermore, these mice exhibited an enhancement of morphine-mediated antinociception in the hot-plate test, as well as a potentiation of opioid inhibition of GABA transmission in the PAG. These data confirm the hypothesis that RGS proteins regulate MOR signaling and antinociception negatively. In contrast, there was no effect of the loss of RGS regulation on methadone antinociception in the hot-plate test, and an unexpected reduction in morphine and methadone antinociception in the tail-withdrawal test. Overall, the results demonstrate that although RGS proteins regulate MOR signaling negatively in the PAG, they alter opioid-mediated antinociception differentially depending upon the agonist and nociceptive pathway(s) involved.

Pretreatment of wild-type mice with NTX did not affect baseline latency in either the hot-plate or the tail-withdrawal test, indicating that endogenous opioid peptide tone is insufficient to cause an antinociceptive response. In contrast, $\mathrm{G} \alpha_{\mathrm{o}}+/ \mathrm{GS}$ mice exhibited a NTX-sensitive increase in baseline latency in both the hot-plate and tail-withdrawal tests compared with wild-type littermates. We ascribe this to enhanced MOR signaling in response to endogenous opioid peptides only in mice expressing $\mathrm{G} \alpha_{\mathrm{o}} \mathrm{RGSi}$ subunits.

Removal of negative regulation of $\mathrm{G} \alpha$ o by RGS proteins also resulted in enhanced morphine-mediated antinociception in the hot-plate test, indicating that RGS proteins function as negative regulators of morphine supraspinal antinociception. In support of this and consistent with the role of RGS proteins as negative regulators of signaling, there was a robust potentiation of morphine or ME inhibition of GABAergic neurotransmission in the PAG from $G \alpha_{\mathrm{o}}+/ \mathrm{GS}$ mice. The ability of opioids to inhibit presynaptic GABA release in the PAG is thought to underlie the production of antinociception (Moreau and Fields, 1986; Reichling et al., 1988).

In contrast to the hot-plate test, morphine antinociception as measured in the tail-withdrawal test was reduced significantly in $\mathrm{G} \alpha_{\mathrm{o}}+/ \mathrm{GS}$ mice. Although a reduction in $\mathrm{G} \alpha_{\mathrm{o}}$ protein was observed in the spinal cord, it is unlikely that $\mathrm{G} \alpha_{\mathrm{o}}$ levels are a limiting factor for morphine spinal antinociception given that a $>50 \%$ loss of $\mathrm{G} \alpha$ o protein did not affect morphine antinociception in the tail-withdrawal test (Lamberts et al., 2011). Therefore, it appears that the reduction in morphine spinal antinociception in $\mathrm{G} \alpha_{\mathrm{o}}+/ \mathrm{GS}$ mice is a direct consequence of the inability of $\mathrm{G} \alpha_{\mathrm{o}}$ RGSi subunits to bind RGS proteins, indicating that 
Whole brain

a
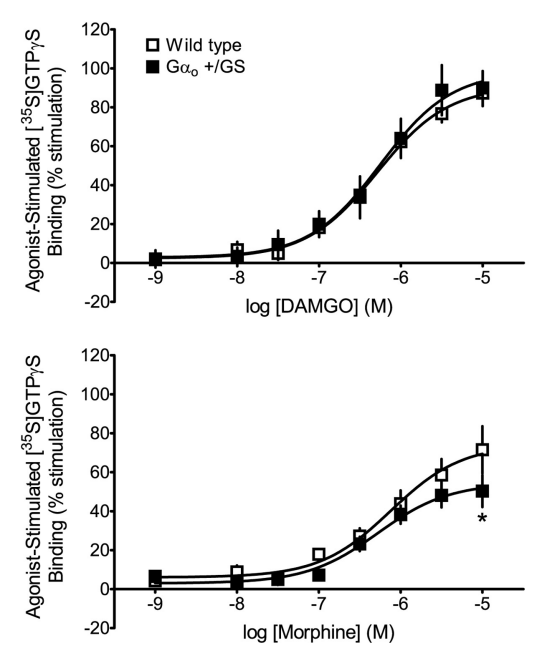

Spinal cord

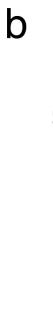

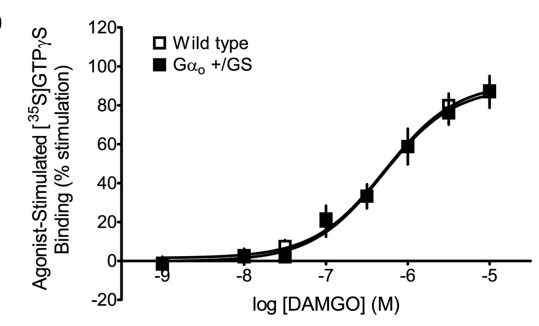

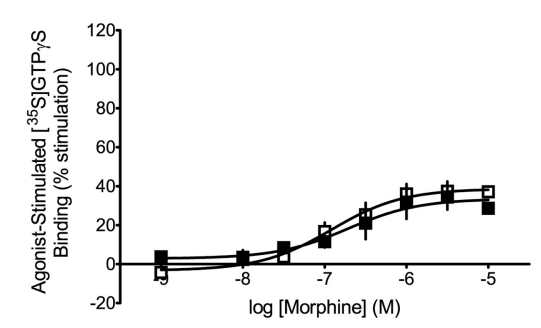

Figure 5. Agonist-stimulated G-protein activity in whole-brain or spinal cord homogenates from wild-type and G $\alpha_{0}+/ G S$ mice. $\boldsymbol{a}, \boldsymbol{b},\left[{ }^{35} \mathrm{~S}\right] \mathrm{GTP} \gamma \mathrm{S}$ binding was measured in whole brain $(n=8-9 ; \boldsymbol{a})$ and spinal cord $(n=3 ; \boldsymbol{b})$ in the presence of increasing concentrations of DAMG0 (top) or morphine (bottom). ${ }^{*} p<0.05$ compared with wild-type mice at the corresponding concentration by Bonferroni's post-test. For all experiments, nonspecific binding was determined using $10 \mu \mathrm{M} \mathrm{GTP} \gamma \mathrm{S}$. Agonist-stimulated $\left[{ }^{35} \mathrm{~S}\right] \mathrm{GTP} \gamma \mathrm{S}$ binding is shown as the percentage stimulation, where percentage stimulation $=[($ drug binding - basal binding $) /$ basal binding] $\times 100$. All data are plotted as the mean \pm SEM.

Table 2. Basal and agonist-stimulated $\left[{ }^{35} \mathrm{~S}\right] \mathrm{GTP} \gamma \mathrm{S}$ binding in membranes from whole brain or spinal cord of wild-type and $G \alpha_{0}+/ G S$ mice

\begin{tabular}{|c|c|c|c|c|}
\hline \multirow[b]{2}{*}{ Tissue } & \multirow[b]{2}{*}{ Genotype } & \multirow{2}{*}{$\begin{array}{l}\text { Basal }\left[{ }^{35} \mathrm{~S}\right] \mathrm{GTP} \gamma \mathrm{S} \\
\text { binding (fmol/mg } \\
\text { protein) }\end{array}$} & \multicolumn{2}{|c|}{$\begin{array}{l}\text { Agonist-stimulated } \\
{\left[{ }^{35} \mathrm{~S}\right] \mathrm{GTP} \gamma \mathrm{S} \text { binding }}\end{array}$} \\
\hline & & & $\begin{array}{l}\text { DAMGO } \\
\mathrm{EC}_{50}(\mathrm{~nm})\end{array}$ & $\begin{array}{l}\text { Morphine } \\
\mathrm{EC}_{50}(\mathrm{~nm})\end{array}$ \\
\hline \multirow[t]{2}{*}{ Whole brain } & Wild type & $65.9 \pm 2.2$ & $524 \pm 39$ & $806 \pm 210$ \\
\hline & $\mathrm{G} \alpha_{0}+/ \mathrm{GS}$ & $46.5 \pm 4.9^{* *}$ & $722 \pm 116$ & $526 \pm 98$ \\
\hline \multirow[t]{2}{*}{ Spinal cord } & Wild type & $66.8 \pm 7.6$ & $547 \pm 103$ & $174 \pm 88$ \\
\hline & $\mathrm{G} \alpha_{0}+/ \mathrm{GS}$ & $45.3 \pm 4.6^{*}$ & $524 \pm 121$ & $332 \pm 113$ \\
\hline
\end{tabular}

${ }^{*} p<0.05$ compared with wild type spinal cord, ${ }^{* *} p<0.01$ compared with wild type whole brain by Student's $t$ test. Data represent the mean \pm SEM (whole brain: $n=8-9$, basal $n=10$; spinal cord: $n=3$, basal $n=5$ ). Each sample was assayed in duplicate.

RGS proteins act as positive regulators of opioid antinociception in this test.

The reason for this differential responsiveness to morphine between the hot-plate and tail-withdrawal tests is not immediately obvious. Systemic morphine acts at both spinal and supraspinal sites, including the PAG, and so activates a variety of MORs. Such MORs may represent different receptor variants (Pasternak, 2001; Meyer et al., 2007) and/or MORs in different neuronal populations may use different signaling mechanisms. For example, presynaptic MORs in the PAG activate a voltagesensitive potassium channel via phospholipase A2 (Vaughan et al., 1997), whereas MORs in the spinal cord do not appear to use this mechanism (Heinke et al., 2011). In contrast, postsynaptic MORs in both the PAG and spinal cord activate G-proteincoupled, inwardly rectifying potassium channels and inhibit voltage-gated calcium channels (Chieng and Christie, 1994; Connor et al., 1999; Heinke et al., 2011). However, different signaling mechanisms may not be the explanation because NTX blocked basal antinociception in $\mathrm{G} \alpha_{\mathrm{o}}+/ \mathrm{GS}$ mice in both the hot-plate and tail-withdrawal tests. This implicates negative regulation of endogenous opioid peptide signaling by RGS proteins, a finding that was confirmed by the electrophysiological measurements in the PAG.
One possible explanation for the discrepancy between baseline and morphine antinociception in the tail-withdrawal test is that the endogenous opioid peptides responsible for the basal antinociceptive tone in $\mathrm{G} \alpha_{\mathrm{o}}+/ \mathrm{GS}$ mice are discretely released at specific synapses, whereas the systemically administered morphine acts at many spinal and supraspinal sites. Morphine may therefore recruit opposing transmitter systems that use $\mathrm{G} \alpha_{\mathrm{o}}$ and so are also subject to regulation by RGS proteins. For example, adrenergic and serotonergic systems are involved in descending antinociceptive pathways (Millan, 2002) and nociceptin has also been reported to modulate opioid antinociception (Mogil et al., 1996; Heinricher et al., 1997; Tian et al., 1997; Scoto et al., 2007). Nevertheless, our findings in $\mathrm{G} \alpha_{\mathrm{o}}+/ \mathrm{GS}$ mice are reminiscent of observations made in RGS9 knock-out mice, in which morphine supraspinal antinociception was enhanced (Zachariou et al., 2003) whereas morphine spinal antinociception was reduced (Papachatzaki et al., 2011). Those previous studies showed that RGS9 was required for the opioid peptide DAMGO to cause hyperpolarization in lamina II dorsal horn neurons, and therefore the investigators suggested that RGS9-2 performs a scaffolding role. However, our results in $\mathrm{G} \alpha_{\mathrm{o}}+/ \mathrm{GS}$ mice indicate that the loss of RGS GAP activity alone is sufficient to observe this phenomenon. The reason for the difference in responses between endogenous opioid peptides and morphine in the tail-withdrawal test could therefore be explained by a predominantly central site (i.e., the PAG) for opioid peptide action and a predominantly spinal effect of systemically administered morphine.

We also observed differences between morphine and methadone in the two antinociceptive tests. In the hot-plate test, methadone was not different between $\mathrm{G} \alpha_{\mathrm{o}}+/ \mathrm{GS}$ mice and their wild-type littermates. In contrast, methadone antinociception in the tail-withdrawal test was shifted to a lower potency, although the effect was less than that seen with morphine. There are reports that RGS proteins can act as either positive or negative regulators of opioid antinociception depending upon the agonist tested. For example, knock-out of RGS9 has been shown to enhance morphine antinociception but to inhibit methadone or fentanyl antinociception in the hot-plate test (Psifogeorgou et al., 2011); conversely, in the tail-withdrawal test, knock-out of RGS4 did not alter morphine-mediated antinociception but did inhibit fentanyl and methadone antinociception (Han et al., 2010). At least for RGS9-2, this effect has been ascribed to agonist-specific formation of complexes containing RGS9-2 and MOR in association with different $\mathrm{G} \alpha$ subunits. However, our current results suggest that the differences observed between morphine and methadone are due to the higher efficacy of the latter compound (Adams et al., 1990; Peckham and Traynor, 2006; McPherson et al., 2010). In support of this, we demonstrated previously that RGS proteins are much less effective in modulating full versus partial agonists (Clark et al., 2003; Clark et al., 2008).

An important caveat to our present findings is that mice expressing $\mathrm{G} \alpha_{\mathrm{o}}$ RGSi subunits exhibited a reduction in both $\mathrm{G} \alpha_{\mathrm{o}}$ protein expression and basal G-protein activity. This loss of $\mathrm{G} \alpha_{\mathrm{o}}$ 
protein is likely a compensatory response to the enhanced signaling activity of $\mathrm{G} \alpha_{\mathrm{o}}$ RGSi subunits. Alternatively, there may be altered expression of the G $\alpha_{\mathrm{o}}$ RGSi mutant allele that contains a nongenomic insertion in exon 5 of Gnaol (Fu et al., 2004; Goldenstein et al., 2009). However, the reduction in $\mathrm{G} \alpha_{\mathrm{o}}$ protein in $\mathrm{G} \alpha_{\mathrm{o}}+/ \mathrm{GS}$ mice was not sufficient to affect the expression of MOR in whole brain or spinal cord, and it had only a small effect on the maximum stimulation of $\left[{ }^{35} \mathrm{~S}\right] \mathrm{GTP} \gamma \mathrm{S}$ binding by the partial agonist morphine in whole brain but not spinal cord. Nevertheless, we cannot discount other compensatory and/or developmental changes in $\mathrm{G} \alpha_{\mathrm{o}}+/ \mathrm{GS}$ mice that may have contributed to the behavioral differences observed in this study. Conversely, the effects we observed in the PAG and on the antinociceptive behavior of both morphine and endogenous opioid peptides are likely to be an underestimate of the degree of RGS modulation of MOR-mediated signaling and behavior given that we used heterozygous mice with only one allele of Gnaol that expresses G $\alpha_{\mathrm{o}}$ RGSi.

In conclusion, the current studies used a novel knock-in mouse model to demonstrate a role for RGS proteins in opioid antinociception mediated specifically by $\mathrm{G} \alpha$. Our results demonstrate that endogenous RGS GAP activity negatively regulates antinociceptive responses to endogenous enkephalins, morphine antinociception in the hot-plate test, and opioid inhibition of GABAergic transmission in the PAG. In contrast, these studies revealed a potential role of RGS protein GAP activity as a positive regulator of morphine and methadone antinociception in the tail-withdrawal assay. Therefore, the present work provides evidence that endogenous RGS proteins are able to regulate differentially diverse nociceptive and antinociceptive pathways that are activated by a single nociceptive modality. Although the importance of the interaction between RGS proteins and $\mathrm{G} \alpha_{\mathrm{o}}$ subunits for MOR function remains to be fully elucidated, this interface could represent a novel target for the development of more effective pain therapeutics and/or new treatments for drug addiction. For example, the fact that $\mathrm{G} \alpha_{\mathrm{o}}+/ \mathrm{GS}$ mice show reduced responsiveness to a noxious stimulus suggests that inhibition of RGS activity alone could afford an antinociceptive effect.

\section{References}

Adams JU, Paronis CA, Holtzman SG (1990) Assessment of relative intrinsic activity of mu-opioid analgesics in vivo by using beta-funaltrexamine. J Pharmacol Exp Ther 255:1027-1032. Medline

Bradford MM (1976) A rapid and sensitive method for the quantitation of microgram quantities of protein utilizing the principle of protein-dye binding. Anal Biochem 72:248-254. CrossRef Medline

Cesselin F, Benoliel JJ, Bourgoin S, Collin E, Phol M, Hamon M (1999) Spinal mechanisms of opioid analgesia. In: Opioids in pain control: basic and clinical aspects (Stein C, ed), pp 70-95. Cambridge, UK: Cambridge UP.

Chieng B, Christie MJ (1994) Hyperpolarization by opioids acting on mureceptors of a sub-population of rat periaqueductal gray neurones in vitro. Br J Pharmacol 113:121-128. CrossRef Medline

Clark MJ, Traynor JR (2004) Assays for G-protein-coupled receptor signaling using RGS-insensitive Galpha subunits. Methods Enzymol 389:155169. CrossRef Medline

Clark MJ, Harrison C, Zhong H, Neubig RR, Traynor JR (2003) Endogenous RGS protein action modulates mu-opioid signaling through Galphao. Effects on adenylyl cyclase, extracellular signal-regulated kinases, and intracellular calcium pathways. J Biol Chem 278:9418-9425. CrossRef Medline

Clark MJ, Linderman JJ, Traynor JR (2008) Endogenous regulators of G protein signaling differentially modulate full and partial mu-opioid agonists at adenylyl cyclase as predicted by a collision coupling model. Mol Pharmacol 73:1538-1548. CrossRef Medline

Connor M, Schuller A, Pintar JE, Christie MJ (1999) Mu-opioid receptor modulation of calcium channel current in periaqueductal grey neurons from C57B16/J mice and mutant mice lacking MOR-1. Br J Pharmacol 126:1553-1558. CrossRef Medline

De Vries L, Zheng B, Fischer T, Elenko E, Farquhar MG (2000) The regulator of G protein signaling family. Annu Rev Pharmacol Toxicol 40:235-271. CrossRef Medline

Fu Y, Zhong H, Nanamori M, Mortensen RM, Huang X, Lan K, Neubig RR (2004) RGS-insensitive G-protein mutations to study the role of endogenous RGS proteins. Methods Enzymol 389:229-243. CrossRef Medline

Fu Y, Huang X, Zhong H, Mortensen RM, D’Alecy LG, Neubig RR (2006) Endogenous RGS proteins and Galpha subtypes differentially control muscarinic and adenosine-mediated chronotropic effects. Circ Res 98: 659-666. CrossRef Medline

Garzón J, López-Fando A, Sanchez-Blázquez P (2003) The R7 subfamily of RGS proteins assists tachyphylaxis and acute tolerance at mu-opioid receptors. Neuropsychopharmacology 28:1983-1990. CrossRef Medline

Garzón J, Rodríguez-Muñoz M, López-Fando A, García-España A, SánchezBlázquez P (2004) RGSZ1 and GAIP regulate mu- but not delta-opioid receptors in mouse CNS: role in tachyphylaxis and acute tolerance. Neuropsychopharmacology 29:1091-1104. CrossRef Medline

Garzón J, Rodríguez-Muñoz M, López-Fando A, Sánchez-Blázquez P (2005) The RGSZ2 protein exists in a complex with mu-opioid receptors and regulates the desensitizing capacity of Gz proteins. Neuropsychopharmacology 30:1632-1648. CrossRef Medline

Goldenstein BL, Nelson BW, Xu K, Luger EJ, Pribula JA, Wald JM, O'Shea LA, Weinshenker D, Charbeneau RA, Huang X, Neubig RR, Doze VA (2009) Regulator of $\mathrm{G}$ protein signaling protein suppression of Galphao proteinmediated alpha2A adrenergic receptor inhibition of mouse hippocampal CA3 epileptiform activity. Mol Pharmacol 75:1222-1230. CrossRef Medline

Grillet N, Pattyn A, Contet C, Kieffer BL, Goridis C, Brunet JF (2005) Generation and characterization of Rgs4 mutant mice. Mol Cell Biol 25:42214228. CrossRef Medline

Han MH, Renthal W, Ring RH, Rahman Z, Psifogeorgou K, Howland D, Birnbaum S, Young K, Neve R, Nestler EJ, Zachariou V (2010) Brain region specific actions of regulator of $\mathrm{G}$ protein signaling 4 oppose morphine reward and dependence but promote analgesia. Biol Psychiatry 67:761-769. CrossRef Medline

Heinke B, Gingl E, Sandkühler J (2011) Multiple targets of mu-opioid receptor-mediated presynaptic inhibition at primary afferent Adelta- and C-fibers. J Neurosci 31:1313-1322. CrossRef Medline

Heinricher MM, Morgan MM (1999) Supraspinal mechanisms of opioid analgesia. In: Opioids in pain control: basic and clinical aspects (Stein C, ed), pp 46-69. Cambridge, UK: Cambridge UP.

Heinricher MM, McGaraughty S, Grandy DK (1997) Circuitry underlying antiopioid actions of orphanin FQ in the rostral ventromedial medulla. J Neurophysiol 78:3351-3358. Medline

Hollinger S, Hepler JR (2002) Cellular regulation of RGS proteins: modulators and integrators of G protein signaling. Pharmacol Rev 54:527-559. CrossRef Medline

Huang X, Fu Y, Charbeneau RA, Saunders TL, Taylor DK, Hankenson KD, Russell MW, D’Alecy LG, Neubig RR (2006) Pleiotropic phenotype of a genomic knock-in of an RGS-insensitive G184S Gnai2 allele. Mol Cell Biol 26:6870-6879. CrossRef Medline

Irwin S, Houde RW, Bennett DR, Hendershot LC, Seevers MH (1951) The effects of morphine methadone and meperidine on some reflex responses of spinal animals to nociceptive stimulation. J Pharmacol Exp Ther 101: 132-143. Medline

Lamberts JT, Jutkiewicz EM, Mortensen RM, Traynor JR (2011) MuOpioid Receptor Coupling to Galpha(o) Plays an Important Role in Opioid Antinociception. Neuropsychopharmacology 36:2041-2053. CrossRef Medline

Lester PA, Traynor JR (2006) Comparison of the in vitro efficacy of mu, delta, kappa and ORL1 receptor agonists and non-selective opioid agonists in dog brain membranes. Brain Res 1073-1074:290-296.

McPherson J, Rivero G, Baptist M, Llorente J, Al-Sabah S, Krasel C, Dewey WL, Bailey CP, Rosethorne EM, Charlton SJ, Henderson G, Kelly E (2010) mu-opioid receptors: correlation of agonist efficacy for signalling with ability to activate internalization. Mol Pharmacol 78:756-766. CrossRef Medline

Meyer PJ, Fossum EN, Ingram SL, Morgan MM (2007) Analgesic tolerance to microinjection of the micro-opioid agonist DAMGO into the ventro- 
lateral periaqueductal gray. Neuropharmacology 52:1580-1585. CrossRef Medline

Millan MJ (2002) Descending control of pain. Prog Neurobiol 66:355-474. CrossRef Medline

Mogil JS, Grisel JE, Reinscheid RK, Civelli O, Belknap JK, Grandy DK (1996) Orphanin FQ is a functional anti-opioid peptide. Neuroscience 75:333-337. CrossRef Medline

Moreau JL, Fields HL (1986) Evidence for GABA involvement in midbrain control of medullary neurons that modulate nociceptive transmission. Brain Res 397:37-46. CrossRef Medline

Neubig RR, Siderovski DP (2002) Regulators of G-protein signalling as new central nervous system drug targets. Nat Rev Drug Discov 1:187-197. CrossRef Medline

Papachatzaki MM, Antal Z, Terzi D, Szücs P, Zachariou V, Antal M (2011) RGS9-2 modulates nociceptive behaviour and opioid-mediated synaptic transmission in the spinal dorsal horn. Neurosci Lett 501:31-34. CrossRef Medline

Pasternak GW (2001) Insights into mu opioid pharmacology: the role of mu opioid receptor subtypes. Life Sci 68:2213-2219. CrossRef Medline

Peckham EM, Traynor JR (2006) Comparison of the antinociceptive response to morphine and morphine-like compounds in male and female Sprague-Dawley rats. J Pharmacol Exp Ther 316:1195-1201. CrossRef Medline

Potenza MN, Gold SJ, Roby-Shemkowitz A, Lerner MR, Nestler EJ (1999) Effects of regulators of $\mathrm{G}$ protein-signaling proteins on the functional response of the mu-opioid receptor in a melanophore-based assay. J Pharmacol Exp Ther 291:482-491. Medline

Psifogeorgou K, Papakosta P, Russo SJ, Neve RL, Kardassis D, Gold SJ, Zachariou $\mathrm{V}$ (2007) RGS9-2 is a negative modulator of mu-opioid receptor function. J Neurochem 103:617-625. CrossRef Medline
Psifogeorgou K, Terzi D, Papachatzaki MM, Varidaki A, Ferguson D, Gold SJ, Zachariou V (2011) A unique role of RGS9-2 in the striatum as a positive or negative regulator of opiate analgesia. J Neurosci 31:5617-5624. CrossRef Medline

Reichling DB, Kwiat GC, Basbaum AI (1988) Anatomy, physiology and pharmacology of the periaqueductal gray contribution to antinociceptive controls. Prog Brain Res 77:31-46. CrossRef Medline

Ross EM, Wilkie TM (2000) GTPase-activating proteins for heterotrimeric G proteins: regulators of $\mathrm{G}$ protein signaling (RGS) and RGS-like proteins. Annu Rev Biochem 69:795-827. CrossRef Medline

Scoto GM, Aricò G, Ronsisvalle S, Parenti C (2007) Blockade of the nociceptin/orphanin $\mathrm{FQ} / \mathrm{NOP}$ receptor system in the rat ventrolateral periaqueductal gray potentiates DAMGO analgesia. Peptides 28:1441-1446. CrossRef Medline

Tian JH, Xu W, Fang Y, Mogil JS, Grisel JE, Grandy DK, Han JS (1997) Bidirectional modulatory effect of orphanin FQ on morphine-induced analgesia: antagonism in brain and potentiation in spinal cord of the rat. Br J Pharmacol 120:676-680. CrossRef Medline

Traynor JR, Neubig RR (2005) Regulators of G protein signaling and drugs of abuse. Mol Interv 5:30-41. CrossRef Medline

Vaughan CW, Christie MJ (1997) Presynaptic inhibitory action of opioids on synaptic transmission in the rat periaqueductal grey in vitro. J Physiol 498:463-472. Medline

Vaughan CW, Ingram SL, Connor MA, Christie MJ (1997) How opioids inhibit GABA-mediated neurotransmission. Nature 390:611-614. CrossRef Medline

Zachariou V, Georgescu D, Sanchez N, Rahman Z, DiLeone R, Berton O, Neve RL, Sim-Selley LJ, Selley DE, Gold SJ, Nestler EJ (2003) Essential role for RGS9 in opiate action. Proc Natl Acad Sci U S A 100:1365613661. CrossRef Medline 